\title{
Human Plasma Derived Drugs Separation by Fractionation of Plasma with Polyethylene Glycol
}

\author{
Kamran Mousavi Hosseini 1,*, Mojgan Pourmokhtar ${ }^{2}$, Mehryar Habibi Roudkenar ${ }^{1}$, Majid Shahabi ${ }^{1}$ \\ ${ }^{1}$ Department of Biotechnology, Blood Transfusion Research Center, High Institute for Research and Education in \\ Transfusion Medicine, P.O. Box 14665-1157, Tehran, I.R. IRAN \\ ${ }^{2}$ Department of Biochemistry, Blood Transfusion Research Center, High Institute for Research and Education in Transfusion \\ Medicine, P.O. Box 14665-1157, Tehran, I.R. IRAN
} *Corresponding Author: Kamran Mousavi Hosseini, Blood Transfusion Research Center, High Institute for Research and Education in Transfusion
Medicine, P.O. Box 14665-1157, Tehran, I.R. IRAN. Tel: +98-2182052160, Fax: +98-2188060717, E-mail: mkmousavi@yahoo.com

Received: June 10, 2014; Revised: September 02, 2014

Background: There are variefy of purification techniques for separation of human plasma proteins such as salting out, ion
exchange chromatography and ethanol fractionation. There are limitations for each method, for example in salting out
method, the salt has to be removed in an additional step. Ion exchange chromatography is difficult for scaling up, and plas-
ma fractionation is a time consuming method and it needs machinery and plants. In the present study the fractionation of
human plasma by polyethylene glycol was investigated.
Objectives: The purpose of this study was to investigate the possibility of the fractionation of human plasma by polyeth-
ylene glycol.
Materials and Methods: Human plasma fractionation was carried out by using polyethylene glycol with different concen-
trations from five to twenty percent, followed by centrifugation. After centrifugation the supernatant was used for further
fractionation by addition of a higher concentration of polyethylene glycol.
Results: Suitable intermediate sources for protein purification were obtained by fractionation of human plasma by polyeth-
ylene glycol. Fibrinogen in fraction $5 \%$, IgG and IgM in fraction $10 \%$, IgA in fraction $20 \%$, and finally albumin and $\alpha_{1}-$
Antitrypsin in supernatant $20 \%$ of polyethylene glycol were achieved.
Conclusions: By our study we could obtain four different fractions as intermediate sources for protein purification which
cannot be easily obtained from plasma fractionation by cold ethanol fractionation.
Keywords: Albumin; Human plasma; Immunoglobulin; Plasma protein

\section{Background}

Human blood as a unique tissue (1), contains many important proteins with therapeutic uses (2). As a biological drugs, virus inactivation is one of the crucial steps in their preparations of these plasma derived proteins (3-6). The most important proteins in human plasma are: albumin, immunoglobulin, fibrinogen, and coagulation factors VII, VIII and IX (7). There are varieties of purification techniques for separation of these proteins (8-11). One of the methods is salting out $(12,13)$. There are not many salts which can be used in this method and most of the researchers use ammonium sulphate for precipitation of plasma protein $(14,15)$. But the problem is fractionation of plasma by ammonium sulphate needs to be repeated several times. The other compound which can be implemented for protein precipita- tion is the lactate of 2-ethoxy-6, 9-diamino-acridine (Rivanol) (16). After plasma fractionation by this substance, it has to be removed from the plasma, which sometimes its complete removal could be difficult. The other method for protein separation is ion exchange chromatography $(17,18)$. So far many commercially available gels have been produced for ion exchange chromatography for which scaling up for industrial scale is not so easy. The quality of plasma play an important role in the quality of final product of plasma fractionation (19). Ethanol fractionation of plasma is a very suitable method for the preparation of albumin, and immunoglobulin in large scale $(20,21)$. However, for separation of protein from human plasma by ethanol fractionation, different equipments are needed that to be installed in a plasma fractionation factory. In our study we used poly- 
ethylene glycol as an alternative method to ethanol plasma fractionation, to investigate protein separation by addition of polyethylene glycol.

\section{Objectives}

The purpose of this study was to investigate the possibility of the fractionation of human plasma by polyethylene glycol.

\section{Materials and Methods}

Human fresh frozen plasma (22) was thawed overnight at $4^{\circ} \mathrm{C}$ in cold room. After centrifugation at $2500 \times g$ of fresh frozen plasma and the removal of the paste, the supernatant was used as starting material. In order to minimize the protein denaturation all procedures were carried out at $4^{\circ} \mathrm{C}$ in the cold room. Solid PEG-4000 which is a water soluble and non-toxic synthetic polymer from Merck-Germany at the concentration of 5\% $(50 \mathrm{~g} / \mathrm{L})$ was added to the cryosupernatant and stirred for $1 \mathrm{~h}$. After centrifugation a 5\% paste was obtained. After removal of the $5 \%$ paste, addition of $50 \mathrm{~g} / \mathrm{L}$ of polyethylene glycol was added to the supernatant to obtain $10 \%$ paste by centrifugation. The $20 \%$ fraction was achieved by addition of 100 $\mathrm{g} / \mathrm{L}$ of PEG to the supernatant and by adding an additional $100 \mathrm{~g} / \mathrm{L}$ of PEG to the supernatant resulted in obtaining of a $30 \%$ paste.

It should be mentioned after each step of PEG addition, the solution was stirred for $1 \mathrm{~h}$, and it was followed by centrifugation at $2500 \times g$ for removal of related paste. By this method we could obtain four fractions of $5 \%, 10 \%, 20 \%$, and $30 \%$ of PEG in addition to fraction of cryosupernatant as starting material which could be compared to those fractions from cold ethanol fractionation.

Determination of fibrinogen was carried out by clotting assay method. Total protein determination was measured by a colorimetric test with biuret reagent from Merck, Germany by using a Philips PU $8750 \quad$ UV/Vis Scanninig Spectrophotometer.

Albumin measurement was carried out by a colorimetric method using bromcresol green (BCG), and determined by reading the absorbance by Philips PU 8750 UV/Vis Scanning Spectrophotometer.

The concentrations of $\operatorname{IgG}, \operatorname{IgA}$, and IgM were measured by immunoturbidimetric test using Immunoglobulin IgG Kit, Immunoglobulin IgA Kit, and Immunoglobulin IgM Kit from Human Diagnostics, Germany by Cobas Mira Photometer from Roche, USA.

\section{Results}

As it has been shown in table 1, albumin is the main contaminant in fraction with 5\% polyethylene glycol, while fibrinogen is the dominant protein in this fraction. Also albumin as contaminant could be observed in fractions $10 \%$ and $20 \%$ of polyethylene glycol. The highest concentration of immunoglobulin $\mathrm{G}$ and immunoglobulin $\mathrm{M}$ could be found in $10 \%$ polyethylene glycol fraction. The fraction 20\% PEG is rich in immunoglobulin A with less amount of IgG and IgM. Albumin and $\alpha_{1}$-Antitrypsin because of their similarity in physicochemical properties are dominant in final supernatant with $20 \%$ PEG. This fraction is a suitable source for albumin and $\alpha_{1}$-antitrypsin preparation.

Human plasma proteins showed different solubility in variations of polyethylene glycol concentrations. In our study plasma fractionation by different concentration of polyethylene glycol resulted in four fractions which is shown in Table 1.

\section{Discussion}

By cold ethanol fractionation of human plasma, five fractions can be achieved $(23,24)$. Table

\begin{tabular}{|c|c|c|c|c|c|}
\hline Proteins & Cryoprecipitate & 5\% PEG & $10 \%$ PEG & $20 \%$ PEG & Final Supernatant \\
\hline Total Protein & 6050 & $302(5.0 \%)$ & $1210(20.0 \%)$ & $660(10.9 \%)$ & $3510(58.0 \%)$ \\
\hline Fibrinogen & 181 & $117(64.6 \%)$ & $31(17.1 \%)$ & $4(2.2 \%)$ & - \\
\hline$\alpha_{1}$-Antitrypsin & 162 & $2(1.2 \%)$ & $5(3.1 \%)$ & $8(4.9 \%)$ & $120(74.1 \%)$ \\
\hline Albumin & 3500 & $110(3.1 \%)$ & $115(3.3 \%)$ & $140(4.0 \%)$ & $2980(85.1 \%)$ \\
\hline $\operatorname{IgG}$ & 715 & $24(3.4 \%)$ & $585(81.8 \%)$ & $96(13.4 \%)$ & $5(0.7 \%)$ \\
\hline $\operatorname{IgA}$ & 152 & $5(3.3 \%)$ & $45(29.6 \% 0)$ & $80(52.6 \%)$ & $26(17.1 \%)$ \\
\hline $\operatorname{IgM}$ & 120 & $8(6.7 \%)$ & $35(29.2 \%)$ & $2(1.7 \%)$ & - \\
\hline
\end{tabular}


Table 2. Proteins distribution in different fractions of plasma fractionation by cold ethanol

\begin{tabular}{lcc}
\hline Fraction & Component & \% of protein \\
\hline I & Fibrinogen & $5-10$ \\
& Factor VIII & \\
II & Immunoglobulin & 25 \\
IV-1 & $\begin{array}{c}\alpha \text {-antitrypsin } \\
\text { Antitrombin III } \\
\alpha \text {-and } \beta \text { globulin }\end{array}$ & $5-10$ \\
& Albumin & \\
V & & $50-60$ \\
\hline
\end{tabular}

2 shows these fractions with approximately recovery of protein. Human plasma fractionation by cold ethanol is a time consuming process and for adjustments of different parameters such as $\mathrm{pH}$, ionic strength, temperature, ethanol concentration, and protein concentration it needs hours for conditioning. It has to be noticed that ethanol may influence protein-protein interactions and there are growing indications that exposure to ethanol affects some of the plasma proteins.

One of the advantages of polyethylene glycol in comparison with ethanol is the shorter period of time of processing, which is required for the precipitation process. Using polyethylene glycol instead of alcohol makes it possible to work at below $0^{\circ} \mathrm{C}$ without the need for extreme temperature control to avoid freezing and it is due to its low heat of PEG solution in water. Different distribution of proteins in fractions with $5 \%$ to $20 \%$ PEG is shown in the Table 1.

Fraction with 5\% PEG is a good source for further purification of fibrinogen, while IgG is dominant in fraction with 10\% PEG. Most of the IgA could be obtained in fraction with 20\% PEG, and at the end final supernatant is a very good source for purification of albumin.

\section{Conclusions}

By our study we could obtain different fractions as intermediate sources for protein purification which cannot be easily obtained from plasma fractionation by cold ethanol fractionation.

In compare with ethanol, polyethylene glycol is nonflammable and is not toxic. Using PEG allowed us working above zero temperature without denaturation of protein, and permitted direct centrifugation without the time period for conditioning which is time consuming in the case of using cold ethanol.

\section{Acknowledgements}

This study was supported by Blood Transfusion Research Center, High Institute for Research and Education in Transfusion Medicine.

\section{Authors' contribution}

Kamran Mousavi Hosseini: Designed and carried out the study and prepared the manuscript. Mojgan Pourmokhtar: Participated in the experimental work of the fractionation and drafting the manuscript. Mehryar Habibi Roudkenar: Was involved in the experimental work of the fractionation. Majid Shahabi: Carried out the analytical methods.

\section{Financial Disclosure}

There was no conflict of interest.

\section{Funding/Support}

The study has been supported by Iranian Blood Transfusion Organization.

\section{References}

1. Reeves JR, Xuan JW, Arfanis K, Morin C, Garde SV, Ruiz MT, Wisniewski J, Panchal C, Tanner JE: Identification, purification and characterization of a novel human blood protein with binding affinity for prostate secretory protein of 94 amino acids. Biochem $J$. 2005;385(1):105-114.doi:10.1042/BJ20040290

2. Yang X, Clifton J, Huang F, Kovac S, Hixson DC, Josic D: Proteomic analysis for process development and control of therapeutic protein separation from human plasma. Electrophoresis 2009;30(7):11851193.doi:10.1002/elps.200800501

3. Rezvan H, Motallebi Z, Jalili MA, Mousavi Hosseini K, Pourfathollah AA: Safety of blood and plasma derivatives: pathogen reducing technologies. Med J Islam Repub Iran. 2006;20(2):86-92.

4. Rezvan H, Nasiri S, Mousavi Hosseini K, Golabi M: A study on the application and efficacy of solvent-detergent treatment in the process of purifying F VII from prothrombin complex. Med J Islam Repub Iran. 2002;16(3):179-182.

5. Mousavi Hosseini K, Rezvan H, Motallebi Z, Chabokpey S, Mirbod V: Iran Biomed J. 2002;6(4):135-140.

6. Rezvan H, Nasiri S, Mousavi Hosseini K: Inactivation of polio-virus type-1 and HSV-1 in human coagulation factor VII concentrate by pasteurization. Arch Iran Med. 2001;4(1):10-13. 
7. Nasiri S, Rezvan H, Mousavi Hosseini K, Roostaei $\mathrm{MH}$ : Preparation of highly purified S/D coagulation F VII and F IX concentrate from PPSSB. Med J Islam Repub Iran. 2001;15(2):103-108.

8. Rigaut G, Shevchenko A, Rutz B, Wilm M, Mann M, Seraphin B: A generic protein purification method for protein complex characterization and proteome exploration. Nat Biotechnol. 1999;17:10301032.doi:10.1038/13732

9. Mousavi Hosseini K, Heidari M, Yari F: The preparation of albumin as a biological drug from human plasma by fiber filtration. Tehran Univ Med J. 2011;69(5):283-288.

10. Sahebghadam Lotfi A, Adibi B, Mousavi Hosseini K, Mahmoodi M: Purification and isolation of á1-proteinase inhibitor and determination of some of its' physicochemical properties. Modarres J Med Sci. 2005;7(2):71-80.

11. Sahebghadam Lotfi A, Mottahari M, Shakibi M, Mousavi Hosseini K, Adibi B. Measurement of serum level of IgA- á1-AT complex in patients with rheumatoid arthritis. Scient J Iran Blood Transfus Organiz. 2005;2(4):65-71.

12. Porath J: Salting-out adsorption techniques for protein purification. Biopolymers 1987;26:193204.doi:10.1002/bip.360260017

13. Von der Harr F: Purification of proteins by fractional interfacial salting out on unsubstitute agarose gels. Biochem Biophys Res Commun. 1976;70(3):1009-1013. doi:10.1016/0006-291X(76)960692-6

14. Kulshrestha Y, Hussain Q: Direct immobilization of peroxidase on DEAE cellulose from ammonium sulphate fractionated proteins of bitter gourd. Enzyme Microb Technol. 2006;38(3-4):470477.doi:10.1016/j.enzmictec.2005.07.001

15. Jiang L, He L, Fountoulakis M: Comparison of protein precipitation methods for sample preparation prior to proteomic analysis. J Chromatogr. 2004;1023(2):317320.doi:10.1016/j.chroma.2003.10.029

16. Minkova K, Gigova L, Tchernov A, Stojanova M, Ivanova $\mathrm{N}$, Boteva $\mathrm{R}$, Tchorbadjieva $\mathrm{M}$ : Isolation of pure c-phycocyanin from arthrospira maxima and arthrospira fusiformis by a modified non-chromatographic Rivanol-sulphate procedure. Comptes rendus de I'Academie bulgare des Sciences. 2007;60(7):795798.

17. Levison PR: Large-scale ion-exchange column chromatography of proteins. J Chromatogr B. 2003;790:1733.doi:10.1016/S1576-023(03)00087-4

18. Mousavi Motlagh S, Rezvan H, Pourfatollah A, Mousavi Hosseini K: Improving purification of coagulation F IX using heparin affinity chromatography and its comparison with ion exchange chromatography. Sci J Iran Blood Transfu Organiz. 2005;2(4):91-98.

19. Mahmoodian Shooshtari M, Mousavi Hosseini K: Evaluation of the plasma quality after filtration. $D A R U$ 2010;18(2):114-117.
20. Burnouf T: Modern plasma Fractionation. Transfu Medicine Rev. 2007; 117.doi:10.1016/j.tmv.2006.11.001

21. Gregori L, Maring JA, MacAuley C, Dunston B, Rentsch M, Kempf, C, Rohwer RG: Partitioning of TSE infectivity durin ethanol fractionation of human plasma. Biologicals 2004;32(1):1-10.doi:10.1016/j.biologicals.2003.08.004

22. Cardigan R, Lawrie AS, Mackie IG, Williamson LM. The quality of fresh frozen-plasma produced from whole blood stored at 4 degree $\mathrm{C}$ overnight. Transfusion 2005;45(8):1342-1348.doi:10.111/j.15372995.2005.00219.x

23. Mousavi Hosseini K, Nasiri S, Heidari M: Using ethanol and low temperature in separation of albumin from human plasma. J Zanjan Univ Med Sci Health Serv. 2013;21(85):65-67.

24. Kovacs A, Guttman A: Medicinal Chemistry meets proteomics: fractionation of the human plasma proteome. Curr Med Chem. 2013;20(4):483490.doi:10.2174/0929867311320040001 